10-1993

\title{
Teachers' Professional Development and Education Reform
}

University of Pennsylvania

Follow this and additional works at: https://repository.upenn.edu/cpre_policybriefs

Part of the Education Policy Commons, and the Teacher Education and Professional Development Commons

\section{Recommended Citation}

University of Pennsylvania. (1993). Teachers' Professional Development and Education Reform. CPRE Policy Briefs.

Retrieved from https://repository.upenn.edu/cpre_policybriefs/51

This document was authored by the Consortium for Policy Research in Education, but no individual authors were identified.

View on the CPRE website.

This paper is posted at ScholarlyCommons. https://repository.upenn.edu/cpre_policybriefs/51

For more information, please contact repository@pobox.upenn.edu. 


\title{
Teachers' Professional Development and Education Reform
}

\author{
Abstract \\ This issue of CPRE Policy Briefs contains excerpts from Little's article, "Teacher Professional \\ Development in a Climate of Educational Reform." The brief addresses the problem of "fit" between \\ current state and local reforms and prevailing approaches to professional development. The first section \\ summarizes the major themes of reform; the second focuses on the policy dilemma these reforms \\ present for professional development; the third describes emerging alternatives to traditional professional \\ development' and the final section suggests principles to guide the design of professional development \\ opportunities.

\section{Disciplines} \\ Education Policy | Teacher Education and Professional Development

\section{Comments} \\ This document was authored by the Consortium for Policy Research in Education, but no individual \\ authors were identified. \\ View on the CPRE website.
}




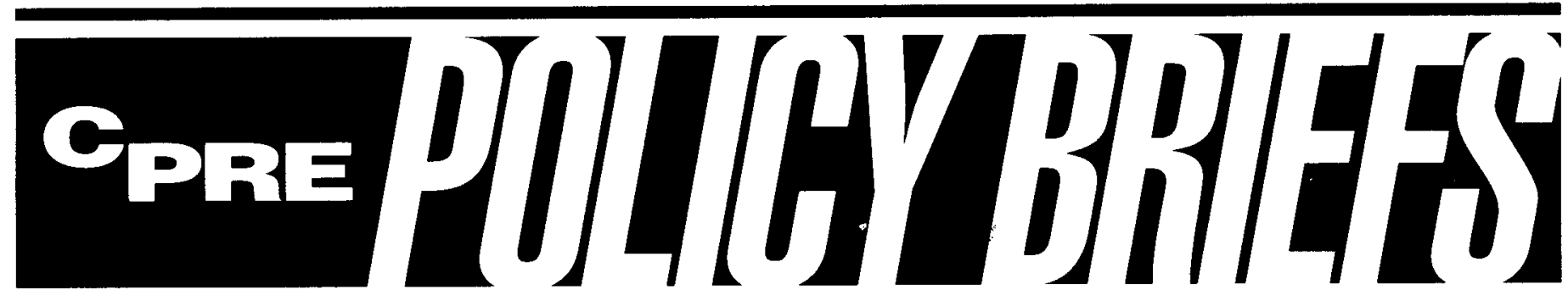

REPORTING ON ISSUES AND RESEARCH IN EDUCATION POLICY AND FINANCE

\section{Teachers' Professional Development and Education Reform}

New curriculum frameworks, new standards for instruction and assessment, new school-level reform approaches-all may hold promise for improving education. But these and other reforms pose tough challenges to teachers and how they teach. And, traditional professional development methods are not likely to equip teachers to be active and effective participants in today's reform efforts, according to a report written for CPRE.

The conventional model of professional development focusses on expanding a teacher's supply of skills and techniques for classroom teaching, says Judith Warren Little.* This "training model" is inadequate, given the ambitious vision of teaching and student learning driving many reform efforts, she argues. However, some emerging alternatives to the training model are more compatible with the complex demands of today's reforms.

This issue of CPRE Policy Briefs contains excerpts from Little's article, “Teacher Professional Development in a Climate of Educational Reform."1 The brief addresses the problem of "fit" between current state and local reforms and prevailing approaches to professional development. The first section summarizes the major themes of reform; the second focuses on the policy dilemma these reforms present for professional development; the third describes emerging alternatives to traditional professional development; and the final section suggests principles to guide the design of professional development opportunities.

\section{Five Streams of Reform and Their Implications for Teaching}

Most current initiatives fit into one or more of five streams of reform. Alone, and in combination, the reforms present intricate challenges to teachers as individuals and as members of a wider professional community. The five streams of reform cannot be done well piecemeal, nor can they succeed if attempted only in isolated classrooms. As Fine (1992) puts it, present ventures pursue the "big systemic educational question" of transforming whole systems into "educationally and emotionally rich communities of learners" (p. 2). The five reform streams are summarized on the next page.

\footnotetext{
*Judith Warren Little is associate professor in the Graduate School of Education at the University of California-Berkeley. Her research interests include professional development policy and practice, schools as workplaces, and teacher careers.
}

${ }^{1}$ The article appears in Educational Evaluation and Policy Analysis 15 (No. 2, Summer 1993):129-151. Copyright 1993, by the American Education Research Association; adapted by permission of the publisher. Preparation of the article and this brief was supported in part by the Evaluating Systemic Reform project of the Office of Educational Research and Improvement, U.S. Department of Education, grant \#RR91172005. 


\section{Reforms in subject-matter teaching (standards, curriculum, \& pedagogy)}

Many of the current reforms aspire to "more ambitious student outcomes." Among them are the whole language and literaturebased approach to language arts, the new National Council of Teachers of Mathematics (NCTM) standards, and the like. These reforms are incompatible with textbook-bound curricula or recitation-style teaching; they demand that teachers be well-able to integrate various content areas into coherent lessons, and to efficiently organize students' time. And these demands may represent a substantial departure from teachers' prior experience, established beliefs, and present practice.

In addition, individual teachers may be pressed to move on many fronts at once. For example, elementary school teachers must absorb the changes in content and method for an entire elementary curriculum. Meanwhile, reforms aimed at critical thinking may be in conflict with the basic skills reforms that began in the 1960 s and are still very much evident today.

\section{Reforms centered on problems of equity and the increasing diversity of the student population}

These reforms address the persistent achievement disparities among students from differing family backgrounds and seek to improve both the demonstrated achievement and school completion rates of the lowest achieving groups. Over past decades, such reforms have focused on remedying individual student deficiencies. Recent analyses have drawn attention to the ways in which school practices define and contribute to student failure
To address the institutional failure related to low achievement, teachers must learn to identify and alter classroom practices that contribute to student failure and undermine "equal opportunity to learn" (Cochran-Smith \& Lytle, 1992; Fecho, 1992).

\section{Reforms in the nature, extent, and uses of student assessment}

Some reform proposals seek more widespread and rigorous use of assessment that truly measures what students are learning. Yet, the technical advances in assessment are lagging behind the advances in curriculum design. State and local policymakers continue to judge the success of reform efforts on the basis of standardized test scores.

Components of statewide tests that strike teachers as most "authentic" (writing samples, openended math reasoning items) are also those that appear difficult and expensive to develop and to score. And at the local level, teachers' interest in alternative forms of assessment far exceeds their professed skill in constructing, evaluating, or incorporating them into their practice. Further, teachers do not have adequate resources available to them from the research and test development communities.

\section{$1 / \begin{aligned} & \text { Reforms in the social } \\ & \text { organization of } \\ & \text { schooling }\end{aligned}$}

In recent years there has been a remarkable convergence of interest, activities, and funds around the broad image of "school restructuring." State-supported initiatives in "school restructuring," foundation-supported special projects, and projects sponsored by teachers' associations in concert with local schools and districts have appeared in nearly every state. The most ambitious of these are based on principles, rather than specific practices. They pose a deep dilemma for school leadership and for professional development programs because there are rarely any well-developed models of how these principles translate into specific instructional strategies and activities.

To provide opportunities for professional development in support of the principled redesign of schooling, then, is a much different matter from organizing training and support to implement a specific program or a set of readily transferable practices.

\section{Reforms in the
professionalization of
teaching}

The "professionalization" reforms at the state level focus on teachers' demonstrated knowledge base (as reflected in standards for accreditation of teacher education programs and candidate assessment), on teacher licensure requirements, and on the structure of career opportunities in teaching. Reforms to professionalize teaching mean that teachers will increasingly serve as mentors to new teachers, take on new responsibilities over time, and exert more leadership through sitebased decision-making.

The many arguments for professionalizing the teaching occupation will not be explored here. However two comments are pertinent. First, policymakers seem most willing to support appeals for professionalization when they believe it will sustain a well-prepared and stable teacher workforce and when they have received assurances of local accountability for student outcomes. Second, these reforms often expand teachers' opportunities and rewards in exchange for increased obligations. 


\section{The Policy Dilemma}

Professional development using conventional training techniques may work reasonably well to introduce those aspects of reforms that are "technical," or involve mastering a repertoire of classroom practices. However, current reforms do not focus so much on teachers acquiring a "knowledge base" of specific, transferable skills. Rather, they require that school staff translate broad principles into day-to-day practice.

Instead of skills training, these reforms call for expanding teachers' opportunities to learn, experiment, consult, and evaluate. Such opportunities must be embedded in the routine organization of the school day and year. This requires the development of structures and cultures compatible with the image of "teacher as intellectual" (Giroux 1988) rather than teacher as technician. Policymakers and school officials confront serious difficulties in matching the existing resources for professional development to such challenges. Major challenges can be summarized under four headings:

\section{Surmounting the limitations of packaged knowledge}

Given the option, district and school administrators prefer "well-packaged programs" of staff development (Little et al., 1987), which are readily defended, managed and evaluated. But such programs are not likely to meet current needs. Alternative approaches, however, are less structured, take more time and may be harder to defend to costconscious school boards. But packaged programs which use research as a warrant for recommending specific practice rather than for informing teachers' judgements miss the opportunity to invite teachers to become critics and producers of research, participants in a more visible and consequential manner.

\section{Spreading innovation beyond the margins}

The training paradigm dominates the world of teachers' professional development and most training places teachers in passive roles as consumers of knowledge produced elsewhere. The "workshop menu" is fragmented in content, form, and continuity-at precisely the time when teachers are confronted with the challenge of redesigning schooling (Moore \& Hyde, 1981; Little, 1989).

On the whole, innovative approaches that depart from the training model remain small in scale and number. Most have been supported with private dollars (foundation and corporate funding) and have had relatively little impact on the configuration of publicly-supported professional development. Risks associated with moving from the margins to the center are well known; even teacher-centered programs risk "bureaucratization" if they are absorbed within existing district structures for professional development.

\section{Centering learning opportunities in the school workplace}

Concentration on formal programs of professional development tends to obscure issues of obligation, incentive, and opportunity in the salaried work day and work year. As the arena in which teaching traditions and reform demands confront one another most sharply, the school workplace is both the most crucial and the most complex of settings for teachers' professional development. Teachers' motivations, incentives, and frustrations

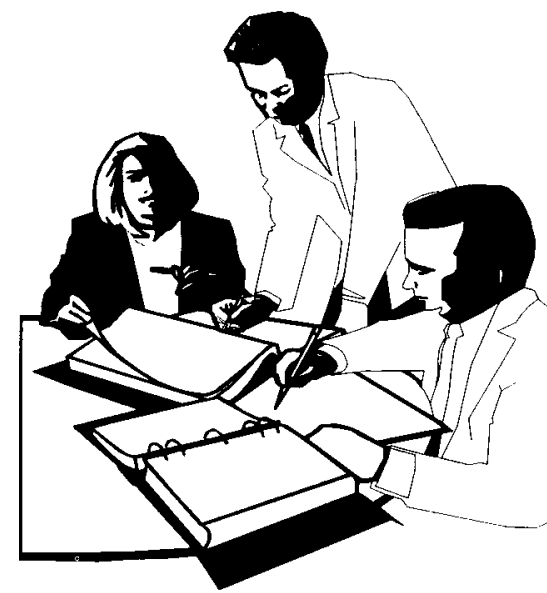

come foremost from their responses to their students and the circumstances in which they teach them. Teachers' desires to protect their autonomy may be intensified by their relations with each other and with administrators. Clearly, transforming the workplace into a site for more effective learning and sharing requires more than shifting staff development resources and activities to the school site.

\section{Deciding the locus of responsibility for professional development policy}

The state and the district are the most prominent players in defining and promoting reform, and in sponsoring formal occasions of professional development. Various professional associations are playing a less visible but potentially influential role. In many districts, school staff also are active participants, setting priorities, content, and character of professional development.

With multiple players and multiple levels of policy and practice in professional development, several questions are relevant. First, what "fit" between reform and professional development is best achieved at each level or niche in the policy system, and through what policy mechanism? To what extent does policymaking at each level rely 
on regulation or persuasion? Second, in what ways and to what extent are the various policy orientations congruent or in conflict? For example, a district's interest in "comprehensive restructuring" may operate to displace small, vital pockets of initiative by teachers in individual schools.

In the absence of a good fit between the nature of the reform task and the nature of professional development, the inclination is nonetheless to do something in the name of professional development. That something is likely to look very much like the existing menu of training options. But such decisions tend to consume all or most of the available resources, while the more ambiguous aspects of reform are granted comparatively less attention or neglected altogether.

\section{Alternatives to Traditional Models}

Alternatives to traditional models rest on the assumption that the best forms of professional development engage teachers in the pursuit of learning in ways that leave a mark on their perspectives and their practice. These approaches communicate a view of teachers as classroom experts, and also as persons embarked on an intellectually demanding career that may span more than 30 years. Examples of these approaches are highlighted below.

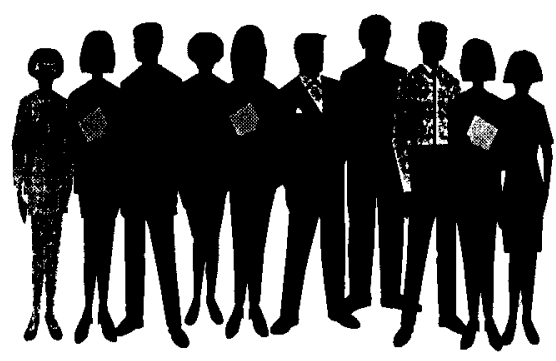

\section{Teacher collaboratives and other networks}

Subject-specific teacher collaboratives in mathematics, science, and the humanities have grown in size, visibility, and influence over the past decade. Brian Lord (1991) says that these subject collaboratives share the view that teachers' professional development encompasses: “(a) teachers' knowledge of academic content, instruction, and student learning, (b) teachers' access to a broader network of professional relationships, and (c) teacher leadership in the reform of systemwide structures " (p. 3).

One example of such a collaborative, the Philadelphia Alliance for Teaching Humanities in the Schools (PATHS) emphasizes engaging teachers directly in the modes of inquiry used by the various humanities disciplines. The project's goal of providing urban students with the "real thing"-a challenging and genuine humanities curriculum-required a parallel experience for teachers.

PATHS teachers work directly with the city's rich humanities collections and with the curators and other experts who acquire, maintain, and interpret them. The teachers take advantage of minigrants which give greater incentives for collaborative work. They also participate in colloquia on major topics, designed as "pure" intellectual experiences, "divorced from the practical considerations of [teachers'] jobs" (Hodgson, 1986, p. 32); and in summer institutes in literature, history, and languages. All the programs are conducted on site where the relevant collections are held.

The collaboratives underscore teachers' involvement in the construction of subject matter knowledge. Without being linked narrowly to specific reform proposals, they prepare teachers to make informed responses to reforms in subject matter teaching and student assessment.

\section{Subject matter associations}

The work of teachers' professional associations is nearly invisible in the mainstream professional development literature. We know little about the roles played by the largest and most prominent subject matter associations (such as the National Council of Teachers of English, and National Council of Teachers of Mathematics) in the professional lives of teachers or in shaping their dispositions toward particular reforms. Yet it is clear that the subject associations are exerting increasingly powerful influences in the design of subject curriculum and assessment standards.

The subject matter associations are professional communities that extend well beyond the school walls, and are independent of the employing organizations but positioned to exert strong influence on teachers' dispositions toward reform proposals. To the extent that an association's most active members also occupy leadership roles within their school, districts, or collective bargaining units, the association's effect may be multiplied.

\section{School-University collaborations targeted at school reform}

Professional development is one integral feature of some schooluniversity collaborations designed to support school reform. But these collaborations have had a rocky history. As instruments of reform, and as sites for professional development, they have had difficulty overcoming longstanding imbalances in status, power, and resources. As these 
partnerships evolve, however, they are moving toward greater parity in obligations, opportunities, and rewards.

The Coalition of Essential Schools, for example, offers the image of the school "friend," the insider/outsider attached to the school to provide support, expand access to resources and to critique school progress.

In one Philadelphia partnership, university faculty, teachers, prospective teachers, and secondary school students are all participants in research into aspects of a multicultural society (CochranSmith \& Lytle, 1992; Fecho, 1992). In this instance, teachers' professional development is intricately interwoven with the daily life of the classroom.

In another example, faculty from National-Louis University are partners with the Chicago Public Schools in support of various subject matter reforms. The goal of this partnership is to promote breakthroughs in conceptual understanding for the teachers and to immerse them in mathematical experiences rather than focusing on mathematical skills or methods. The program aims to provide professional development that is much broader than training and that engages local teachers in a leadership role.

On the whole, these partnerships have formed between individual activists in universities and schools or districts, or between individual consultants and schools, or between departments of education and local schools. They have not routinely incorporated faculty from subject matter departments. And in large institutions, multiple "partnerships" may operate in ignorance of one another's efforts. Despite such difficulties, collaborations

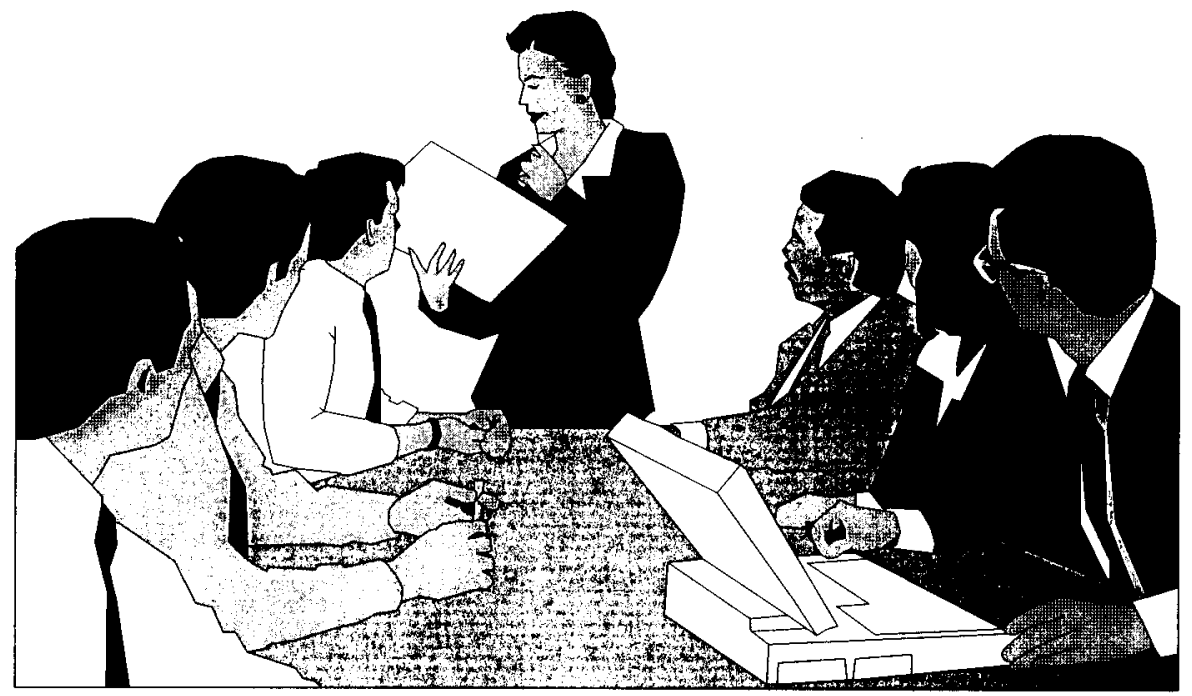

hold promise as vehicles for more effective professional development.

\section{Special institutes and centers}

Among the accounts that teachers offer when they are asked to describe favorable professional development experiences, certain stories stand out. They describe participation in special institutes or centers where teachers enjoy sustained work with ideas, materials, and colleagues. Teachers say such institutes and centers offer great depth and focus, enough time to grapple with ideas and materials, the sense of doing real work rather than being "talked at," and an opportunity to consult with colleagues and experts.

Compared to the volume of studies examining district-sponsored training or school improvement projects, research on the effectiveness of institutes and centers is rare. Anecdotal evidence points to two important policy issues: scale and scope. These organizations concentrate resources, meaning more cost per participant and less access than more modest local ventures. Further, it is not clear how participation by relatively few teachers would affect the larger education community.

\section{Professional \\ Development Principles and Practices}

Each of the alternative professional development approaches described above embrace (more or less) certain principles that may fit the complexity of current reforms. Each principle represents a challenge to some aspect of present practice. Teachers' professional development might reasonably be tested against these principles:

\section{- Professional development should offer meaningful intel- lectual, social, and emotional engagement with ideas, with materials, and with colleagues both in and out of teaching.}

This principle challenges training programs that contain shallow, fragmented content and call on teachers to passively implement reforms developed elsewhere. It also acknowledges teachers' limited access to the intellectual resources of their communities and subject fields.

\section{- Professional development should take explicit account of the contexts of teaching and the experience of teachers.}

This is a challenge to the "one size fits all" approach of staff development that offers standard- 
ized content to teachers whose experience, expertise and workplaces vary widely.

\section{- Professional development should offer support for informed dissent.}

To permit or even foster dissent (such as by creating structures for devil's advocate arguments) places importance on the evaluation of alternatives and the close scrutiny of underlying assumptions. In such a system, dissenters may be less likely to be labelled as "resisters."

\section{- Professional development should place classroom prac- tice in the larger contexts of school practice and the educa- tional careers of children.}

This is a challenge to a narrow, technological view of curriculum reform that emphasizes the accumulation of specific skills and treats teachers at classroom decision-makers independent of larger patterns of practice.

\section{- Professional development should prepare teachers (and students and parents) to use the techniques and perspec- tives of inquiry.}

While there are times when technical skill training is appropriate, this principle looks to a model based more strongly on the pursuit of knowledge. It acknowledges that the existing knowledge base for teaching is relatively slim and that educational strength may come less from teachers' willingness to consume research findings than from their capacity to generate knowledge and assess knowledge claimed by others.

\section{- Professional development should balance support for institutional initiatives with support for those initiated by teachers individually and collectively.}

vacuum in the allocation of professional development resources. Few states or districts have any mechanism for setting professional development priorities and tracing how the entire configuration of professional development obligations and opportunities aligns with their views of schools, teachers, teaching, and teacher development. Evaluation and research tend to focus on individual activities or projects rather than on the policy import of whole patterns of resource allocation.

\section{Conclusion}

This brief does not suggest that the training model is without merit. The training-coaching strategy that dominates local professional development has shown consistent results when training content can be represented as a repertoire of discrete practices and where classroom performance is oriented toward specified student outcomes. And the best local activities incorporate the wealth of research on effective training and support.

However, the content of much training communicates a view of teaching and learning that is at odds with current reform initiatives. The five streams of reform discussed in this brief present a challenge of considerable complexity, scope, and ambiguity. Yet common professional development requires little of teachers in the way of intellectual struggle or emotional engagement, and takes only superficial account of their histories or circumstances.

The training strategy, appropriately linked to those aspects of teaching that are correctly viewed as transferable skills, can play a useful role in a broader approach to professional development. But it cannot meet the challenges of today's reforms on its own.
To spur widespread improvement of professional development, we must be willing to search for and develop ambitious models that reflect the principles of engagement with ideas, context, and sustained inquiry discussed above.

Whatever the shortcomings of the knowledge base on which current reforms stand, there is enough knowledge to move forward. We have the "knowledge, methods, assessment strategies to transform our classrooms into engaging, critical and creative sites of intellectual growth and personal development" (Fine 1992, p. 30).

However, the success of the trailblazing individuals and institutions will rest ultimately on a crucial fund of political will. Policymakers, administrators and teachers themselves must make professional development a priority in the current reform climate.

\section{References}

Cochran-Smith, M. and S. L. Lytle. (1992). Interrogating Cultural Diversity: Inquiry and Action. Paper presented at the annual meeting of the American Educational Research Association, San Francisco.

Fecho, B. (1992). Language Inquiry and Critical Pedagogy: Coinvestigating Power in the Classroom. Paper presented at the annual meeting of the American Educational Research Association, San Francisco.

Fine, M. (1992). Chart [er]ing Urban School Reform: Philadelphia Style. Philadelphia: CUNY Graduate Center/Philadelphia Schools Collaborative.

Fine, M. (1991). Framing Dropouts: Notes on the Politics of an Urban Public High School. Albany: State University of New York Press.

Giroux, H. A. (1988). Teachers as Intellectuals: Toward a Critical Pedagogy of Learning. Granby, MA: Bergin \& Garvey. 
Hodgson, J. (1986). “Teaching Teachers: Museums Team up with Schools and Universities." Museum News. (June) 2835.

Little, J. W. (1989). "District Policy Choices and Teachers' Professional Development Opportunities." Educational Evaluation and Policy Analysis, 11(2), 165-179.

Little, J. W., W. H. Gerritz, D. S. Stern, J. W. Guthrie, M. W. Kirst, and D. D. Marsh. (1987). Staff Development in California: Public and Personal Investment, Program Patterns, and Policy Choices. San Francisco: Far West Laboratory for Educational Research and Development.

Lord, B. (1991). Subject-Area Collaboratives, Teacher Professionalism, and Staff Development. Paper presented at the annual meeting of the American Educational Research Association, Chicago.

Moore, D., and A. Hyde. (1981). Making Sense of Staff Development: An Analysis of Staff Development Programs and their Costs in Three Urban School Districts. Chicago: Designs for Change.

Oakes, J. (1985). Keeping Track: How Schools Structure Inequality. New Haven: Yale University Press.

\section{The Consortium for Policy Research in Education}

CPRE Policy Briefs are published occasionally by the Consortium for Policy Research in Education. The Consortium operates two separate, but interconnected research centers: The Policy Center and The Finance Center.

CPRE is funded by the U. S. Department of Education's Office of Educational Research. The Policy Center is supported by grant \#OERIR117G1007; the Finance Center is supported by grant \#OERI-R117G10039.

Members of CPRE are: Rutgers, The State University of New Jersey; the University of Wisconsin-Madison; Harvard University; the University of Michigan; and Stanford University.

The views expressed in CPRE publications are those of individual authors and are not necessarily shared by the Consortium, its institutional members, or the U. S. Department of Education.

\section{New Report from CPRE}

Ten Years of State Education Reform: Overview with Four Case Studies

Diane Massell and Susan H. Fuhrman

November 1993 (No. RR-028), \$15.

This report examines 10 years of reform following publication of $A$ Nation at Risk in 1983. It focuses on policy developments and reform trends, discussing the activity of federal, state, and local interests. The report includes analysis and case studies of reform in four states (California, Florida, Georgia and Minnesota) and highlights research findings from seven additional states.

\section{New Book Sponsored by CPRE} Designing Coherent Education Policy: Improving the System

Susan H, Fuhrman, editor

Available from Jossey-Bass, Inc., 350 Sansome St., San Francisco, CA 94194; 415-433-1767 (310 pp., \$32.95).

This book offers the first in-depth look at systemic school reform. It shows educators at the district, state, and federal levels how to coordinate various elements of the policy infrastructure around a new set of ambitious, common goals for what students should know and be able to do.

\section{Policy and Finance Briefs available from CPRE}

Graduating from High School: New Standards in the States

Repeating Grades in School: Current Practice and Research Evidence

Decentralization and Policy Design

Putting the Pieces Together: Systemic School Reform

Equality in Education: Progress, Problems and Possibilities

Keeping College Affordable: A Proposal from Two Economists

Ten Lessons about Regulation and Schooling

Developing Content Standards: Creating a Process for Change

New Fiscal Realities in Higher Education

School-Based Management: Strategies for Success

School Finance Reform: The Role of the Courts

To order CPRE publications write (please include your check): CPRE - Carriage House at the Eagleton Institute of Politics • Rutgers University • 86 Clifton Avenue • New Brunswick, NJ 08901-1568. For information call 908-932-1331. 